\title{
Clinical Profile and Nursing Diagnosis of Patients at Risk of Pressure Ulcers
}

\author{
Amália de Fátima Lucena ${ }^{1}$ \\ Cássia Teixeira dos Santos ${ }^{2}$ \\ Ana Gabriela da Silva Pereira² \\ Miriam de Abreu Almeida ${ }^{3}$ \\ Vera Lucia Mendes Dias ${ }^{4}$ \\ Melina Adriana Friedrich ${ }^{2}$
}

This cross-sectional study characterizes patients at risk of Pressure Ulcers (PUs) and identifies their corresponding Nursing Diagnoses (NDs). The sample consisted of 219 hospitalizations of adult patients at risk for developing a PU established through the Braden Scale. Data concerning the results of the application of the Braden Scale were retrospectively collected from the patients' medical files and statistically analyzed. Most patients were elderly women hospitalized for an average of nine days, affected by cancer, cerebrovascular, lung, cardiovascular and metabolic diseases. The most frequent NDs were Risk for infection, Self-care deficit syndrome, Bathing/ hygiene self-care deficit, Impaired physical mobility, Imbalanced nutrition: less than body requirements, Ineffective breathing pattern, Impaired tissue integrity, Acute pain, Impaired urinary elimination, Impaired skin integrity, and Risk for impaired skin integrity. We conclude that most NDs are common in clinical nursing practice.

Descriptors: Nursing Diagnoses; Nursing Process; Pressure Ulcer; Nursing Care; Protocols.

\footnotetext{
${ }^{1}$ Ph.D. in Sciences. Adjunct Professor, Escola de Enfermagem, Universidade Federal do Rio Grande do Sul, RS, Brazil. E-mail: fatimalucena@ terra.com.br.

2 Nursing undergraduate student, Escola de Enfermagem, Universidade Federal do Rio Grande do Sul, RS, Brasil. E-mail: Cássia: cassia.teixeira87@hotmail.com, Ana Gabriela: agpereira@hcpa.ufrgs.br, Melina: mefriedrich@hcpa.ufrgs.br.

3 Ph.D. in Education. Adjunct Professor, Escola de Enfermagem, Universidade Federal do Rio Grande do Sul, RS, Brazil. E-mail: miriam.abreu@terra.com.br.

${ }^{4}$ RN, Hospital de Clínicas de Porto Alegre, RS, Brazil. E-mail: vdias@hcpa.ufrgs.br.
}

Corresponding Author:

Amália de Fátima Lucena

Universidade Federal do Rio Grande do Sul. Escola de Enfermagem

Departamento de enfermagem-médico-cirúrgica

Rua São Manoel, 963

Bairro: Rio Branco

CEP: 90620-110 Porto Alegre, RS, Brasil

E-mail: afatimalucena@gmail.com 


\section{Perfil clínico e diagnósticos de enfermagem de pacientes em risco para úlcera por pressão}

Estudo transversal, cujos objetivos foram caracterizar os pacientes em risco para úlcera por pressão (UP) e identificar os seus diagnósticos de enfermagem (DEs). A amostra consistiu de 219 hospitalizações de pacientes adultos em risco para UP, determinado pela escala de Braden. Os dados foram coletados, retrospectivamente, em registros da escala de Braden e em prontuário eletrônico e, após, analisados estatisticamente. A maioria dos pacientes era de mulheres, idosos, com tempo de internação mediano de nove dias e portadores de doenças cerebrovasculares, pulmonares, cardiovasculares, metabólicas e neoplásicas. Os DEs mais frequentes foram risco para infecção, síndrome do déficit no autocuidado, déficit no autocuidado: banho/higiene, mobilidade física prejudicada, nutrição desequilibrada: menos do que as necessidades corporais, padrão respiratório ineficaz, integridade tissular prejudicada, dor aguda, alteração na eliminação urinária, integridade da pele prejudicada, risco para prejuízo da integridade da pele. Conclui-se que esses DEs, na maioria, são comuns à prática clínica de enfermagem.

Descritores: Diagnóstico de Enfermagem; Processos de Enfermagem; Úlcera por Pressão;

Cuidados de Enfermagem; Protocolos.

\section{Perfil clínico y diagnósticos de enfermería de pacientes en riesgo de contraer úlcera por presión}

Se trata de un estudio transversal con objetivos de caracterizar a los pacientes en riesgo de contraer úlcera por presión (UP) e identificar sus diagnósticos de enfermería (DEs). La muestra consistió de 219 hospitalizaciones de pacientes adultos en riesgo de contraer UP, determinado por la Escala de Braden. Los datos fueron recolectados retrospectivamente en registros de la Escala de Braden en ficha electrónica y, analizados estadísticamente. La mayoría de los pacientes fueron mujeres, ancianos, con tiempo de internación promedio de nueve días y portadores de enfermedades cerebrovasculares, pulmonares, cardiovasculares, metabólicas y neoplásicas. Los DEs más frecuentes fueron Riesgo de infección, Síndrome de déficit en el autocuidado, Déficit en el Autocuidado: baño/higiene, Movilidad física perjudicada; Nutrición desequilibrada: menos que las necesidades corporales, Estándar respiratorio ineficaz, Integridad tisular perjudicada, Dolor agudo, Alteración en la eliminación urinaria, Integridad de la piel perjudicada, Riesgo para perjuicio de la integridad de la piel. Se concluye que estos DEs, en la mayoría, son comunes a la práctica clínica de enfermería.

Descriptores: Diagnóstico de Enfermería; Procesos de Enfermería; Úlcera por Presión; Atención de Enfermería; Protocolos.

\section{Introduction}

The Nursing Process consists of a method to systematize care provided to individuals, family and communities, as well as to support decision-making and communication among nurses. From this perspective, terminologies and classifications are developed as instruments to describe diagnoses, interventions and nursing outcomes in order to give visibility to nursing practice $^{(1-2)}$.

Since the end of the 1970s, the Hospital de Clinicas of Porto Alegre (HCPA) has used a nursing process based on Horta's theoretical framework(3) including stages of anamnesis and physical assessment, diagnosis, nursing 
prescription, implementation of nursing interventions and nursing computerized evaluation ${ }^{(1-2)}$. The Nursing Diagnoses (NDs) introduced in 2000 were grouped according to the psychobiological, psychosocial and psychospiritual needs and described according to the vocabulary of NANDA-I ${ }^{(4)}$.

The practice of computerized nursing prescription is based on NDs and their related factors or risks (etiologies). There are care actions corresponding to each etiology of an ND, which are selected according to the clinical judgment of the nurse who prescribes it. Such care is based on the body of knowledge found in nursing literature, on the clinical practices of nurses and on the Nursing Classification of Interventions (NIC) ${ }^{(2,5)}$.

Care protocols also help to qualify nursing care in the HCPA. Hence, in 2006 a protocol to prevent and treat PUs was developed(6). PUs are lesions on the skin and/ or subjacent tissue, usually over a bony prominence, which occurs as a consequence of pressure or pressure combined with shearing and/or friction. Although PUs are avoidable most of the time, they are a high-incidence problem for hospitalized patients, requiring the adoption of preventative measures and efficient treatment ${ }^{(7-10)}$.

Identifying individuals at risk of PUs does not depend only on the clinical abilities of professionals but also on the use of an appropriate evaluation instrument. The Braden Scale has indices with an appropriate predictive validity, sensitivity and specificity and has been translated and validated for the Portuguese language. This motivated the choice to use it as the instrument to predict risk for $\mathrm{PU}$ at $\mathrm{HCPA}^{(6,9,11)}$.

The Braden Scale, composed of six subscales (sensory perception, moisture, activity, mobility, nutrition, friction and shearing $)^{(12-14)}$ is applied to patients at their admission into HCPA, re-applied weekly and with each change in a patient's general condition; scores below or equal to 13 determine patient risk for $\mathrm{PUs}^{(6)}$. This evaluation also supports a rational diagnostic process and the implementation of nursing interventions according to a care protocol. A reduced incidence of PUs has been observed in this facility since the implementation of this protocol, which is some evidence of the qualification of nursing care. However, the clinical characteristics of patients at risk for PU, their main NDs and related factors and risks were unknown, as were the cases in which a prescription of interventions described in the care protocol were selected.

Therefore, this study characterizes the clinical profile of patients hospitalized in the HCPA at risk of developing
PUs. It identifies the NDs and their most frequent related factors or risks established for these patients; and also identifies those to whom the prescription of the nursing intervention "Implement PU prevention and treatment protocol" was applied. This intervention is composed of a set of actions ${ }^{(5)}$ established in the care protocol to prevent and treat PUs within this facility.

This study is also justified by the fact that despite the extensive literature on the clinical situation of PUs(8-9,13,15-16), up to the time this study was published, there were no Brazilian studies associating the clinical situation of PUs with nursing diagnoses. One of the few studies addressing the topic was an American study that presents the stages of the nursing process related to the care provided to patients at risk for $\mathrm{PUs}^{(17)}$.

\section{Methods}

This cross-sectional study was conducted in the HCPA at the Federal University of Rio Grande do Sul, Brazil. The sample included 219 hospitalizations of adult patients in clinical and surgical units at risk for PU established by scores below or equal to 13 on the Braden scale ${ }^{(6,14)}$. Missing information regarding the reasons patients were hospitalized and comorbidities associated with NDs reduced the sample to 194 hospitalizations in the analysis stage. Data related to the first semester of 2008 were retrospectively collected. In the first stage, existing data originated from the application of the Braden Scale and records from the patients' medical files available online were collected. Then, NDs and nursing prescriptions were collected from the computerized system. All data were organized in Excel spreadsheets and statistically analyzed through the Statistical Package for the Social Sciences - SPSS version 16.0 . The project was approved by the Ethics Health Research Committee at the institution (protocol no 08-319) and all the researchers signed a form acknowledging their commitment and responsibility concerning the use of data.

\section{Results}

The average age of the patients was 67 years old ( \pm 20.2). Women predominated (132/67\%); average time of hospitalization was nine days ( \pm 27 ); most of the hospitalizations (129/59\%) were in medical clinic units.

The most frequent scores obtained were as follows. A score of 2 (very limited) was obtained in 109 (50\%) 
cases concerning the subscale 'perception'; score of 3 (occasionally moist) was obtained in 92 (42\%) cases concerning 'moisture'; score of 1 (bedfast) was obtained in $182(83 \%)$ cases in the subscale 'activity'; score of 2 (very limited) was obtained in 184 (84\%) cases related to 'mobility'; in the case of 'nutrition', score of 2 (probably inadequate) was obtained in 132 (60\%) cases; score of
1 (problem) was obtained in the subscale 'friction and shearing' in 115 (52.5\%) cases. Scores can vary from one to four in the first three subscales and from one to three in the last subscale. Forty-six NDs were identified in the 219 hospitalizations, while 11 were the most frequent (Table 1 ).

Table 1 - NDs most frequently identified in patients at risk for PUs and their main related factors or risks. Porto Alegre, Brazil, 2010

\begin{tabular}{|c|c|c|c|c|c|}
\hline NDs & $\mathbf{n}$ & $\%$ & Related factor/risk & $\mathbf{n}$ & $\%$ \\
\hline Risk for infection & 120 & 55 & Invasive procedures & 117 & 97 \\
\hline Self-care deficit syndrome & 102 & 46.5 & Neuromuscular/musculoskeletal impairment & 102 & 100 \\
\hline Bathing/hygiene self care deficit & 95 & 43 & Evolution of the disease & 39 & 41 \\
\hline Impaired physical mobility & 70 & 32 & Neuromuscular/musculoskeletal impairment & 38 & 54 \\
\hline \multirow{2}{*}{ Ineffective breathing pattern } & \multirow[b]{2}{*}{57} & \multirow[b]{2}{*}{26} & Neuromuscular/musculoskeletal impairment & 18 & 34 \\
\hline & & & Airway infectious processes & 17 & 29 \\
\hline Imbalanced nutrition: less than body requirements & 53 & 24 & Altered metabolism or increased caloric needs & 17 & 29 \\
\hline Impaired tissue integrity & 45 & 20.5 & Mechanical trauma & 25 & 56 \\
\hline Acute pain & 44 & 20 & Trauma & 29 & 66 \\
\hline Impaired urinary elimination & 30 & 14 & Neuromuscular/skeletal impairment & 13 & 43 \\
\hline Impaired Skin integrity & 29 & 13 & Physical Immobilization & 22 & 76 \\
\hline Risk for impaired skin integrity & 29 & 13 & Physical Immobilization & 18 & 62 \\
\hline
\end{tabular}

In some cases, the same patient presented more than one ND and/or more than one related factor/risk in the same hospitalization (Table 1 ). Five NDs required the selection and prescription of the nursing intervention "Implement PU prevention and treatment protocol" (Table 2).

Table 2 - NDs for which the intervention "Implement PU prevention and treatment protocol" was prescribed. Porto Alegre, Brazil, 2010

\begin{tabular}{lccc}
\hline \multicolumn{1}{c}{ NDs } & Hospitalizations & Prescription of intervention \\
\hline Self-care deficit syndrome & 102 & 89 & \\
Impaired skin integrity & 29 & 22 & 77.3 \\
Risk for impaired skin integrity & 29 & 20 & 7.9 \\
Impaired physical mobility & 70 & 28 & 40 \\
Impaired tissue integrity & 45 & 10 & 22.2 \\
\hline
\end{tabular}

The main reasons patients were hospitalized were cerebrovascular disease (49/22.4\%), lung disease $(34 / 15.5 \%)$, cardiovascular diseases (30/13.7\%), and cancer $(30 / 13.7 \%)$. The most frequent comorbidities were cardiovascular $(88 / 40 \%)$, cerebrovascular $(82 / 37 \%)$ and metabolic $(60 / 27 \%)$ diseases.

The most prevalent NDs and those directly related to risks posed to the skin were compared to the reasons for hospitalizations and comorbidities in order to verify their frequency in each of the situations (Table 3). The Ineffective breathing pattern was the second most frequent ND in patients who were hospitalized due to lung disease and Impaired physical mobility was the second most frequent in patients hospitalized due to cancer. Twenty-five hospitalizations were excluded in this stage due to lack of information, thus the sample was reduced to 194 hospitalizations. 
Table 3 - Main reasons for hospitalizations and comorbidities for patients at risk of PU associated with the main NDs. Porto Alegre, Brazil - 2010

\begin{tabular}{|c|c|c|c|c|c|c|}
\hline \multirow{3}{*}{ Main reasons of hospitalizations } & \multicolumn{6}{|c|}{ Nursing Diagnosis } \\
\hline & \multicolumn{2}{|c|}{$\begin{array}{l}\text { Self-care deficit } \\
\text { syndrome }\end{array}$} & \multicolumn{2}{|c|}{ Risk for infection } & \multicolumn{2}{|c|}{$\begin{array}{c}\text { Bathing/hygiene Self-care } \\
\text { deficit }\end{array}$} \\
\hline & f & $\%$ & $\mathbf{f}$ & $\%$ & f & $\%$ \\
\hline Cerebrovascular $(n=43)$ & 23 & 53 & 19 & 44 & 16 & 37 \\
\hline Lung $(n=30)$ & 18 & 60 & 14 & 47 & - & - \\
\hline Cardiovascular $(n=26)$ & 11 & 42 & 13 & 50 & 12 & 46 \\
\hline Cancer $(n=26)$ & - & - & 17 & 65 & 12 & 46 \\
\hline \multicolumn{7}{|l|}{ Main comorbidities } \\
\hline Cardiovascular $(n=81)$ & 38 & 47 & 40 & 49 & 4 & 5 \\
\hline Cerebrovascular $(n=75)$ & 38 & 51 & 31 & 41 & 27 & 36 \\
\hline \multirow[t]{2}{*}{ Metabolic $(n=53)$} & 27 & 51 & 28 & 53 & 2 & 4 \\
\hline & \multicolumn{6}{|c|}{ Nursing Diagnosis } \\
\hline \multirow[t]{2}{*}{ Main reasons of hospitalizations } & \multicolumn{2}{|c|}{$\begin{array}{c}\text { Risk for impaired skin } \\
\text { integrity }\end{array}$} & \multicolumn{2}{|c|}{ Impaired skin integrity } & \multicolumn{2}{|c|}{ Impaired tissue integrity } \\
\hline & f & $\%$ & f & $\%$ & f & $\%$ \\
\hline Cerebrovascular $(n=43)$ & 5 & 12 & 5 & 12 & 5 & 12 \\
\hline Lung $(n=30)$ & 3 & 10 & 4 & 13 & 2 & 7 \\
\hline Cardiovascular $(n=26)$ & - & - & 4 & 15 & 5 & 19 \\
\hline Cancer $(n=26)$ & 6 & 23 & 2 & 8 & 5 & 19 \\
\hline \multicolumn{7}{|l|}{ Main comorbidities } \\
\hline Cardiovascular $(n=81)$ & 4 & 5 & 14 & 17 & 15 & 18 \\
\hline Cerebrovascular $(n=75)$ & 8 & 11 & 17 & 23 & 13 & 17 \\
\hline Metabolic $(n=53)$ & 3 & 6 & 9 & 17 & 7 & 13 \\
\hline
\end{tabular}

$\mathrm{f}=$ frequency of patients with ND and the reason of hospitalization or associated comorbidity

$\mathrm{n}=$ total number of patients for each reason of hospitalization or comorbidity associated with at least one of the described NDs.

The average scores of each Braden subscale were analyzed in patients who presented at least one of the 11 most frequent NDs. The subscales 'activity' and 'mobility' were those that presented the lowest scores in all the NDs: 1.19 and 1.89 respectively. The lowest score (1.00) was obtained in the subscale 'activity' in patients with the ND Risk for impaired skin integrity.

\section{Discussion}

Most of the studied patients were elderly women hospitalized for an average of nine days, mostly in clinical hospitalization units. Old age is indicated as one of the most relevant factors involved in PUs' physiopatogenesis, especially when associated with morbid conditions such as neurological, mental, nutritional, mobility and activity alterations, and anal and urinary incontinence ${ }^{(9,16,18-}$ 19). These factors characterize a population prone to PU development, recurrence and complications, which consequently requires an increased average time of hospitalization, which in turn may worsen the population's health condition and also increase the costs of treatment ${ }^{(9,15,20)}$.

In HCPA, patient risk for PUs is determined by total scores below or equal to 13 on the Braden Scale.
The establishment of such a risk took into account the hospital's characteristics. This facility is linked to the Unified Health System (SUS) and has a large demand for hospitalizations of severe patients with conditions characterized as having high complexity. The importance of defining a cut-off point is based on the need to delimit the patient's risk of PUs and to direct specific preventive actions to these patients, thereby preventing the implementation of avoidable measures for the largest possible number of patients ${ }^{(6,11)}$.

The most frequent NDs identified in the studied patients present important points to be discussed. The first is the prevalence of some NDs also identified in other studies evaluating groups with characteristics similar to those of the patients evaluated in this study, such as age (around 65 years old), hospitalization-especially in clinical and surgical units-and the presence of chronic diseases and associated comorbidities ${ }^{(21-24)}$. Among the most frequent NDs identified in these studies are Risk for infection, Bathing/hygiene self-care deficit, Impaired Physical Mobility, Imbalanced nutrition: less than body requirements and Acute pain. This fact leads us to the conclusion that these NDs are common in nursing practice; these are often independent of the cause of the 
patient's disease but accompany changes in the level of basic needs for the functioning of their bodies (21-24).

Another point is the peculiarities of each ND. Risk for infection was the most prevalent (120/55\%); preventing this complication has been increasingly addressed in hospitals in order to avoid its occurrence as much as possible(22-23). In addition, the studied patients are mostly elderly individuals with associated comorbidities that predispose them to infections due to reduced immunity.

The second most frequent ND was Self-care deficit syndrome $(102 / 46.5 \%)$, the third was Bathing/hygiene self-care deficit (95/43\%), and the fourth ND was Impaired physical mobility (70/32\%). These were the main factors related to neuromuscular/musculoskeletal impairment and evolution of disease. It shows that these patients have impaired mobility, which affects the performance of daily living tasks, both given their advanced age and their aggravated health conditions ${ }^{(21-22)}$.

It is known that changes caused by aging and also by disease may limit an individual's ability to perform daily living tasks, such as taking a shower, dressing, defecating and urinating without help, feeding oneself, walking, sitting and standing up. These limitations are factors that contribute to an increased risk for PUs and may themselves be worsened by the absence of appropriate interventions.

Neuromuscular and/or musculoskeletal impairment was also the main factor associated with the NDs Ineffective breathing pattern, the fifth most frequent (57/26\%), and Impaired urinary elimination, which was the ninth most frequent (30/14\%), indicating a risk for PUs. Patients with Impaired urinary elimination also presented an average score of 2.55 on the subscale 'moisture'(14-15), implying that patients will be moist or occasionally moist and, therefore, at risk of acquiring PUs.

The ND Imbalanced nutrition: less than body requirements was the sixth diagnosis in terms of frequency $(53 / 24 \%)$ and the subscale 'nutrition' also obtained low scores among these patients (1.91 in average), which confirms the likelihood of an imbalanced nutritional pattern. It is important to bear in mind that in these cases malnutrition may be present or there may be limitations on the normal ingestion of food or fluids, which leads to the need for interventions to improve the nutritional state of patients and reduce the risk and incidence of $\mathrm{PUS}^{(25)}$

The ND Acute pain was the eighth (44/20\%) most frequent diagnosis and was common in hospitalized patients ${ }^{(23)}$. Nursing is increasingly concerned with the treatment and care provided to patients with pain, which is considered the fifth vital sign at HCPA.

The NDs Impaired tissue integrity, the seventh most frequent (45/20.5\%), Impaired skin integrity, tenth most frequent (29/13\%), and Risk for Impaired skin integrity, the eleventh $(29 / 13 \%)$ most frequent, are the ones that best describe risk for PUs or the PUs themselves when their related factors and risks are considered(4). However, these were also the last NDs identified in the studied group even though these patients, previously evaluated through the Braden Scale, were considered at risk for PUs.

The patients with the ND Impaired skin integrity also presented the lowest scores in the subscales 'activity' (1.20), 'mobility' (1.72) and 'moisture' (1.92). Those with the ND Risk for Impaired skin integrity obtained an average score of 1.0 (the lowest possible) in the subscale 'activity' and 1.78 in 'mobility', which corroborates the presence of factors and risks related to these NDs. Hence the conclusion is that the Braden Scale is an excellent instrument to evaluate patient risk for PU and determine the ND Risk for impaired skin integrity as recommended by NANDA-I, since its subscales evaluate risk factors described in this classification ${ }^{(4,14,17)}$.

The most frequent factor related to the 11 NDs was neuromuscular and/or musculoskeletal impairment, which demonstrates to some degree that nurses applied clinical reasoning since this factor indicates the possibility of a lower score in the subscales 'activity' and 'mobility', which in fact presented the lowest scores. The subscale with the lowest average score was 'activity' (between 1.00 and 1.36) followed by 'mobility' (between 1.72 and 2.03), characterizing a bedridden, immobilized or very limited patient.

The nursing intervention "Implement PU prevention treatment protocol" was selected and prescribed for the NDs Self-care deficit syndrome, Impaired skin integrity, Risk for impaired skin integrity, Impaired physical mobility and Impaired tissue integrity. All of them had risks or factors related to signs and symptoms that indicate harm to the skin, and thereby the need for intervention as proposed in the PU care protocol. This raises a question as to the reason some of the NDs such as Impaired skin integrity and Risk for impaired skin integrity, which are specific for patients known to be at risk for PU, were not more frequently identified.

One likely explanation is that the other NDs identified also have, as related factors, reasons that explain risk to skin such as neuromuscular and/or musculoskeletal impairment. There is however a tendency to establish 
NDs common to nursing clinical practice, e.g. 'Risk for infection', when others could more precisely define a given situation. This leads to the issue of diagnostic accuracy, which is based on the assumption that there is a great variety of potential diagnoses in diverse clinical situations. Nurses need to be able to apply the most precise clinical judgment possible.

The need to improve diagnostic accuracy was also observed when the NDs Self-care deficit syndrome and Risk for infection were identified as the most frequent diagnoses, regardless of the reason for hospitalization or comorbidity presented by patients (cerebrovascular, lung or cardiovascular diseases and cancer).

These pathologies, which were the comorbidities or reasons that led to the hospitalizations of patients, can be debilitating and harm one's health, consequently making the individual more vulnerable to PUs. This view agrees with the results of a study that evidenced that diabetes mellitus, hypertension, cardiovascular and respiratory diseases are significant for the development of $\mathrm{PUs}{ }^{(8)}$.

Although other health professionals in addition to nurses need to be involved in the prevention and treatment of PUs given their multiple causes, nursing traditionally plays a crucial role in this process considering the conditions that lead to the development of such ulcers.

Hence, the prevention and treatment of PUs pass through the adoption of care actions implemented for patients, the permanent education of professionals, guidance provided to family members and caregivers, and also the commitment of the institution to provide the conditions required to deliver appropriate care ${ }^{(20)}$. Therefore, a prevention and treatment protocol and the establishment of accurate nursing diagnoses constitute alternatives to achieve excellence in nursing care provided to PUs, since the adoption of best practices can reduce PUs incidence and favor treatment(27).

\section{Conclusions}

The patients at risk for PU were mostly elderly women hospitalized in clinical units, particularly for cerebrovascular, lung, cardiovascular diseases and cancer, with comorbidities related to the cardiovascular, cerebrovascular and metabolic diseases.

Eleven NDs were most frequently identified for these patients, which presented as the main related factor Neuromuscular and/or musculoskeletal impairment, with low scores in the subscales 'activity' and 'mobility' of the Braden Scale. It leads to the conclusion that these are bedridden patients with impaired mobility and who therefore require, in addition to a precise diagnosis, an appropriate care plan with preventive measures and qualified nursing evaluation.

The NDs Self-care deficit syndrome and Risk for infection were prevalent regardless of the reason of hospitalization or comorbidity, which demonstrates that NDs are common in clinical nursing practice. In turn, the NDs related to risk to skin or tissue such as Impaired skin integrity and Impaired tissue integrity were less frequent, contrary to the idea that these would be more prevalent in patients previously identified as being at risk for PUs. This fact points to one of this study's limitations and the need to more deeply investigate this subject and conduct further research in the field of diagnostic accuracy.

The nursing intervention "Implement PU prevention and treatment protocol" was selected for the nursing prescription in the cases of patients who presented NDs with risks or factors related to skin harm, hence the PU is correctly treated when the ND is accurate.

We highlight that the Braden Scale is applicable as an instrument to evaluate patient risk for PUs and can support the identification of the ND Risk for impaired skin integrity. NANDA-I recommends the use of a risk prediction instrument to establish this ND. It is one of the main innovations and implications for nursing practice in this study, which also presented the description of the most frequent NDs established for these patients and the situations in which the intervention that composes the PU care protocol was implemented.

The role of nurses is crucial in this context because they are the professionals who select data, establish NDs, select, prescribe and/or perform the intervention and evaluate the outcome obtained by patients. For that, nurses are required to know not only the characteristics of patients but also identify in patients the main factors and risks related to different care situations, such as PUs.

\section{Acknowlegments}

The authors thank the participation of nurses of the Wounds Prevention and Treatment Program and the support provided by the

Fund for Research and Events at the Hospital de Clínicas de Porto Alegre. 


\section{References}

1. Almeida MA, Longaray VK, De Cezaro P, Barilli SLS. Correspondência entre cuidados para pacientes com problemas ortopédicos e a classificação das intervenções de enfermagem. Rev Gaúcha Enferm. dez 2007;28(4):480-8.

2. Lucena AF, de Barros AL. Nursing Diagnoses in a Brazilian Intensive Care Unit. Int J Nurs Terminol Class. $2006 \mathrm{Jul} / \mathrm{Sep} ; 17(3): 139-46$.

3. Horta WA. Processo de enfermagem. São Paulo: EDUSP; 1979. $99 \mathrm{p}$.

4. North American Nursing Diagnosis Association. Nursing diagnoses: definitions \& classification 20092011. Philadelphia: Wiley-Blackwell; 2009. 435 p.

5. Dochterman MJ, Bulechek GM. Classificação das intervenções de enfermagem (NIC). 4.ed. Porto Alegre (RS): Artmed; 2008. 988 p.

6. Menegon DB, Bercini RR, Brambila MI, Scola ML, Jansen MM, Tanaka RY. Implantação do protocolo assistencial de prevenção e tratamento de úlceras de pressão do Hospital de Clínicas de Porto Alegre. Rev HCPA $2007 ; 27(2): 61-4$.

7. Blanes L, Duarte IS, Calil JA, Ferreira LM. Avaliação clínica e epidemiológica das úlceras por pressão em pacientes internados no Hospital São Camilo. Rev Assoc Med Brás 2004; 50(2):182-7.

8. Rogenski NMB, Santos VLCG. Estudo sobre a incidência de úlceras por pressão em um hospital universitário. Rev. Latino-Am. Enfermagem. jul-ago 2005;13(4):474-80.

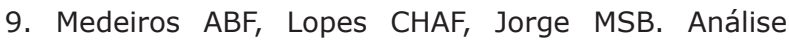
da prevenção e tratamento das úlceras por pressão propostos por enfermeiros. Rev ESC Enferm USP. 2009;43(1):223-8.

10. National pressure ulcer advisory panel [internet]. Washington (EUA). [acesso 22 jun 2010]. Disponível em: http:// < www.npuap.org >.

11. Paranhos WY, Santos VLCG. Avaliação de risco para úlceras de pressão por meio da escala de Braden, na língua portuguesa. Rev Esc Enferm USP. 1999;33(nº esp):191-206.

12. Lyder C. Pressure Ulcer: Prevention and Management. What are known risk factors for pressure ulcers. Annual Rev Nurs Res. 2002;20:35-62.

13. Courtney $\mathrm{H}$, Lyder ND. Pressure Ulcer Prevention and Management. J Am Med Assoc. 2003 January;289(2):223-6.

14. Braden B, Bergstrom N. A conceptual schema for the study of the etiology of pressure sore. Rehabil Nurs. 1987 Jan-Feb;12(1):8-12.

15. Souza DMST; Santos VLCG. Fatores de risco para o desenvolvimento de úlceras por pressão em idosos institucionalizados. Rev. Latino-Am. Enfermagem. setout $2007 ; 15(5)$ :958-64.
16. Cremasco MF, Wenzel F, Sardinha FM, Zanei SSV, Whitaker IY. Úlcera por pressão: o risco e gravidade do paciente e carga de trabalho de enfermagem. Acta Paul Enferm. 2009; 22(esp 70 anos):897-902.

17. Magnan MA, Maklebust J. The nursing process and pressure ulcer prevention: making the connction. Adv Skin Wound Care. 2009 February;22(2):83-92.

18. Lyder C, Preston J, Grady J, Scinto J, Allman R, Bergstrom N, Rodeheaver G. Quality of care for hospitalized medicate patients at risk pressure ulcer. Arch Intern Med. 2001; 161(12):1549-54.

19. Chayamiti EMPC, Caliri MHL. Úlcera por pressão em pacientes sob assistência domiciliária. Acta Paul Enferm. 2010;23(1):29-34.

20. Anselmi ML, Peduzzi M, França I Júnior. Incidência de úlcera por pressão e ações de enfermagem. Acta Paul Enferm. 2009;22(3):257-64.

21. Almeida MA, Aliti GB, Franzen $E$, Thomé EGR,Unicovsky MR, Rabelo ER, et al. Diagnósticos de enfermagem e intervenções prevalentes no cuidado ao idoso hospitalizado. Rev. Latino-Am. Enfermagem. julho-ago 2008;16(4):707-11.

22. Sakano LM, Yoshitome AY. Diagnósticos e intervenções de enfermagem em idosos hospitalizados. Acta Paul Enferm. 2007;20(4):495-8.

23. Volpato MP, Cruz DALM. Diagnósticos de enfermagem de pacientes internadas em unidade médico-cirúrgica. Acta Paul Enferm. 2007;20(2):119-24.

24. Santos ASR, Souza PA, Valle AMD, Cavalcanti ACDC, Sá SP, Santana RF. Caracterização dos diagnósticos de enfermagem identificados em prontuários de idosos: um estudo retrospectivo. Texto Contexto Enferm. jan-mar 2008;17(1):141-9.

25. Clark M. Diretrizes de nutrição na prevenção e tratamento de úlceras de pressão. European Pressure Ulcer Advisory Panel (EPUAP) nov 2003. Registered Charity No: 1066856.

26. Rodrigues RAP, Scudeller PG, Pedrazzi EC, Schiavetto FV, Lange C. Morbidade e sua interferência na capacidade funcional de idosos. Acta Paul Enferm. 2008;21(4):643-8.

27. Fernandes LM, Caliri, MHL. Uso da escala de braden e de glasgow para identificação do risco para úlceras de pressão em pacientes internados em centro de terapia intensiva. Rev. Latino-Am. Enfermagem. 2008;16(6):73-8. 